\title{
Bodybuilding protein supplements and cow's milk allergy in adult
}

\author{
Allergology Department, Centro Hospitalar de Vila Nova de Gaia/Espinho, Portugal
}

\author{
KEY WORDS \\ adult-onset cow's milk allergy; \\ cow's milk proteins; gastrointestinal \\ symptoms; protein supplements; \\ bodybuilding

\section{Corresponding author} \\ Maria João C.S. Sousa \\ Serviço de Imunoalergologia \\ Rua Conceição Fernandes \\ 4434502 Vila Nova de Gaia, Portugal \\ E-mail: mariaj.sousa@gmail.com
}

\section{Doi}

10.23822/EurAnnACI.1764-1489.28

\begin{abstract}
Summary
We report a case of a previously healthy 24-year-old man with a 3-month history of gastrointestinal symptoms during exercise and also few minutes after the ingestion of cow's milk (CM) without exercise. He reported the ingestion of a blend of hydrolyzed whey and casein proteins for bodybuilding for the last 2 years. The in vivo tests showed positivity to $C M$, $\alpha$-lactalbumin, $\beta$-lactoglobulin and casein extracts, and also to the protein supplement. The serum specific IgE was positive for $C M$, $\beta$-lactoglobulin and $\alpha$-lactalbumin. The in vivo and in vitro tests results suggested an IgE-mediated CMA. Adult-onset CMA has been rarely reported, and to our knowledge this is the first case possibly related to bodybuilding supplements. The authors theorize that the presentation of large amounts of proteins in the gastrointestinal tract may favor sensitization.
\end{abstract}

\section{Previous presentation}

The data reported in this study was presented by Maria João Sousa (co-authors: Ferreira AR, Moreira Silva JP) at the EAACI Congress 2015 in Barcelona (Spain) 6-10 June 2015, as a poster entitled "Adult-onset cow's milk allergy and Bodybuilding: is there a connection?".

It was awarded the Poster Prize (Thematic Poster Session 54) and was published in the abstract form in Allergy 2015; 70(Suppl. S101):611; at the 36a Reunião Anual da Sociedade Portuguesa de Alergologia e Imunologia Clínica in Coimbra (Portugal) 9-11 October 2015, as a poster entitled "Alergia às proteínas do leite de vaca: uma apresentação incomum”.

It was awarded the $1^{\text {st }}$ Poster Prize (Poster Session IV) and was published in the abstract form in Rev Port Imunoalergologia 2015; 23(Suppl. 1):64.

\section{Introduction}

Food allergy is characterized by a specific immune response that reproducibly occurs upon exposure to a given food (1). Cow's milk (CM) is one of the main causes of food allergy in the first years of life, but adult-onset cow's milk allergy (CMA) is rare, with an estimated prevalence of $0.49-0.6 \%$ (2). The mechanisms underlying sensitization after the first years of life are unknown. Diagnosis of food allergies should be based on a thorough patient history, skin tests, specific IgE and confirmed by double-blind, placebo-controlled food challenge (DBPCFC) (1).

\section{Case report}

The authors report the case of a 24-year-old man referred to our Allergology Department for suspected CMA. He reported a 3-month history of recurrent episodes of abdominal discomfort 
and nausea during physical exercise, with progressive worsening to abdominal pain and vomiting. These reactions occurred exclusively during exercise at the gym, and the symptoms improved without medication in a few hours. These complaints were never associated with mucocutaneous, respiratory or cardiovascular manifestations; the patient had never attended the emergency department, nor previously sought medical care for those complaints. Later, the patient noticed that reproducible symptoms were also elicited few minutes after the ingestion of $\mathrm{CM}$, which he previously tolerated, without association with exercise. The patient had no previous history of allergy or intolerance to foods or drugs, nor other atopic manifestations.

When questioned about food ingestion prior to exercise, he reported the regular ingestion of protein supplements for muscle building before and during exercise at the gym for the last 2 years, and for the last 2 months he noticed moderate rhinoconjunctivitis symptoms while preparing it. These protein blends are used as a food supplement for improving athletic performance and muscular mass, and the one the patient ingested consisted of a protein blend of high concentration of hydrolyzed whey protein isolates (a mixture of mostly $\beta$-lactoglobulin and $\alpha$-lactoalbumin) with 24 grams of whey protein per dose (dose: $30.4 \mathrm{~g}$ of supplement). Previously, he changed the supplement for another one containing mostly casein (25 grams of protein per dose; dose: $31 \mathrm{~g}$ of supplement) but the abdominal symptoms remained during exercise, as well as rhinoconjuntivitis during preparation. We stress that one dose of these supplements has a protein content about 8 times the amount of protein in cow's milk (3-3.5 g).

Later, he started a $100 \%$ vegetable protein supplement, with tolerance, and continued physical activity uneventful. Few weeks later, after the development of oral allergy symptoms with yogurt and cheese, he began avoidance of dairy products, maintaining ingestion of baked products with milk, as cookies and cakes.

On admission to our department, physical examination was normal. Skin prick tests (SPT) using commercial extracts of aeroallergens, milk and milk proteins (Bial-Aristegui, Bilbao, Spain) were performed and interpreted as previously described (3). Skin prick-to-prick tests (SPPT) with CM, casein and vegetable supplements were also performed. SPT were positive to cow's milk $(12 \mathrm{~mm}), \alpha$-lactalbumin $(16 \mathrm{~mm}), \beta$-lactoglobulin $(9.5 \mathrm{~mm})$ and casein $(8.5 \mathrm{~mm})$ extracts, and negative for all other allergens tested (including mammalian meats). SPPT were positive to $\mathrm{CM}$ and the casein supplement aforementioned, and negative for the vegetable supplement. The results of laboratory studies (full blood count, erythrocyte sedimentation rate, serum electrolytes, and liver and renal function tests) were within normal range. Total and specific IgE (sIgE) to cow's milk and cow's milk proteins were measured using ImmunoCAP FEIA system ${ }^{\circledR}$
(Thermo Fisher Scientific, Uppsala, Sweden). Total serum IgE was $37.5 \mathrm{KU} / \mathrm{L}$; sIgE was positive for CM $(18.20 \mathrm{KU} / \mathrm{L})$, for $\beta$-lactoglobulin $(12.80 \mathrm{KU} / \mathrm{L})$ and for $\alpha$-lactalbumin $(10.50$ $\mathrm{KU} / \mathrm{L})$, and negative for casein $(0.08 \mathrm{KU} / \mathrm{L})$. Lactose intolerance was excluded by a negative Hydrogen Breath Test. The patient refused to perform oral food challenge with milk.

Patient education included a written emergency plan and a prescription of anti-histamine and systemic corticosteroids, to be used in case of allergic reaction upon accidental exposure, maintaining the ingestion of tolerated foods with baked milk. A reevaluation appointment after 4 months was scheduled, but the patient did not attend. After telephone contact, the patient mentioned to keep avoidance of cow's milk and dairy products without history of adverse reactions with accidental exposure.

\section{Discussion}

Adult-onset CMA has been rarely reported, and to our knowledge this is the first case possibly related to bodybuilding protein supplements. This patient never had a previous history of food allergy, which makes us assume that this is an adult-onset CMA. Data on CMA in adults are scarce (4). CMA in adults is more likely to be severe and persistent in adults $(4,5)$. Previous studies have shown that spontaneous tolerance in adult CMA rarely occurs $(4,6)$, and during follow-up DBPCFC should be used to evaluate tolerance acquisition (4).

The immunological mechanisms that lead to the development of CMA are still not clarified. To prevent an indiscriminate immunization, secondary to the absorption of foreign antigens through the gastrointestinal barrier, the gut has developed nonspecific, non-immunological mechanisms, and specific, immunological factors, such as the production of secretory $\operatorname{IgA}$ and antigen interaction with the Gut Associated Lymphoid Tissue (GALT). In normal individuals, antigen presenting cells, mostly dendritic cells (in GALT), process food antigens and present them on a major histocompatibility complex class II receptor to $\mathrm{T}$ cells, resulting in a status of immunologic homeostasis known as oral tolerance, characterized by the deletion of antigen-specific $\mathrm{T}$ cells and production of regulatory $\mathrm{T}$ cells (Treg) that suppress inflammatory responses to antigens (7).

A defect in oral tolerance is thought to be the underlying cause of food allergy (8). A decreased immune response towards foreign antigens, resulting in dysfunction on Treg cellular activity, seems to be the necessary background for both IgE- and non IgE-mediated CMA (9). The increased antigenic load combined with factors such as atopic predisposition, may initiate an abnormal mucosal immune response resulting in chronic enteropathy (10). Gastrointestinal symptoms in food allergy have been explained by alterations in transport across the intestinal wall (increased secretory and/or decreased absorptive functions), increased permeability and mobility of the intestine (10). 
The authors theorize that, in this patient, a temporary dysfunction of the protective mechanisms with loss of tolerance may have occurred. The presentation of large amounts of CM proteins in the gastrointestinal tract (increased antigenic load), associated with exercise (increased intestinal permeability), may have favored sensitization and allergy. The widespread use of protein supplements may contribute to adult-onset CMA prevalence increase.

\section{Conflict of interest}

The authors declare that they have no conflict of interest

\section{References}

1. Boyce JA, Assa'ad, Burks AW, Jones SM, Sampson HA, Wood RA, Plaut M, Cooper SF, Fenton MJ, Arshad SH, Bahna SL, Beck La, Byrd-Bredbenner C, Camargo CA Jr, Jones C, Kraft M, Levy BD, Lieberman P, Luccioli S, McCall KM, Schneider LC, Simon Ra, Simons FE, Teach SJ, Yawn BP, Schwaninger JM. Guidelines for the diagnosis and management of food allergy in the United States: report of the NIAID-sponsored expert panel. J Allergy Clin Immunol 2010; 126(Suppl 6):S1-S58.

2. Luyt D, Ball H, Makwana N, Green MR, Bravin K, Nasser SM, Clark AT. BSACI guideline for the diagnosis and management of cow's milk allergy. Clin Exp Allergy 2014; 44(5):642-72.
3. Dreborg S, Frew A. Position paper: Allergen standardization and skin tests - The European Academy of Allergology and Clinical Immunology. Allergy 1993; 48(Suppl 14):48-82.

4. Lam HY, van Hoffen E, Michelsen A, Guikers K, van der Tas CHW, Bruijnzeel-Koomen CAFM, Knulst AC. Cow's milk allergy in adults is rare but sever: both casein and whey proteins are involved. Clin Exp Allergy 2008; 38(6):995-1002.

5. Ebisawa M, Ballmer-Weber BK, Vieths S (Eds). Food Allergy: Molecular basis and clinical practice. Chem Immunol Allergy. Basel, Karger 2015; (vol. 101):114-23.

6. Stöger P, Wüthrich B. Type I allergy to cow milk proteins in adults. A retrospective study of 34 adult milk- and cheese-allergic patients. Int Arch Allergy Immunol 1993; 102(Suppl 4):399-407.

7. Schmidt-weber CB, Blaser K. T-cell tolerance in allergic response. Allergy 2002; 57(9):762-8.

8. Fiocchi A, Schünemann HJ, Brozek J, Restani P, Beyer K, Troncone R, Martelli A, Terracciano L, Bahna SL, Rancé F, Ebisawa M, Heine RG, Assa'ad A, Sampson H, Verduci E, Bouygue GR, Baena-Cagnani C, Canonica W, Lockey RF. Diagnosis and rationale for action against cow's milk allergy (DRACMA): a summary report. J Allergy Clin Immunol 2010; 126(6):1119-28.

9. Giovanna V, Carla C, Alfina C, Domenico PA, Elena L. The immunopathogenesis of cow's milk protein allergy (CMPA). Italian Journal of Pediatrics 2012; 23(38):1-5.

11. Ahmed T, Fuchs GJ. Gastrointestinal allergy to food: a review. J Diarrhoeal Dis Res. 1997; 15(Suppl 4):211-23. 